been for tournaments or festivities, where nobles might don the persona of the perilous Landsknecht. Perhaps in this very armor, Rogendorf is known to have participated in such spectacles, as well as triumphal entries into cities. Krause also considers the more practical battlefield functions of this armor as reconstructed from existing additional or interchangeable parts and others pieces that are lost. Scholar Andreas Zajic contributes to this volume with a chronicle of the history of the little-known Rogendorf family, its rise and abrupt fall, and their patronage of art and participation in the culture of collectingentirely new research that puts the armor into wide perspective. The final chapter by Krause reviews the armor's provenance, how it came to survive in the Hapsburg armory, and the history of its display at the Kunsthistorisches Museum.

This work brings together an exciting array of brilliantly photographed supportive illustrations, many of which are fresh and rarely reproduced. For example, costume historians will recognize the images from Matthäus Schwarz's Book of Clothes, but perhaps less known is a naïve but revealing sketch of a Landsknecht by Paul Dolnstein from the Thüringisches Hauptstaatsarchiv. In the guise of a digestible coffee-table book, Krause uses this exceptional armor as an insightful window into Renaissance culture. This tightly woven narrative, a synthesis of original visual and written documentation, will be a valuable and lasting resource for scholars of the period.

Jonathan Tavares, Art Institute of Chicago

\title{
The Bible and the Printed Image in Early Modern England: Little Gidding and the Pursuit of Scriptural Harmony. Michael Gaudio. \\ Visual Culture in Early Modernity 52. London: Routledge, 2017. x + 196 pp. \$150.
}

On his way to York in 1642, Charles I paid a visit to the community of Little Gidding where he examined the harmony of the Pentateuch recently completed for the Prince of Wales by the Ferrar/Collet family. Charles's interest in Little Gidding began in the early 1630 s and he commissioned a number of biblical concordances from the community, noting, "How happy a prince were I if there were many such virgins in my kingdom that would employ themselves as these do at Gidding." Yet these were no ordinary biblical concordances. As Michael Gaudio explains in this excellent study, they are composite or patchwork texts made up of printed religious images and biblical verses. The organization of the concordances was established by Nicholas Ferrar, while the work of selection, cutting, arranging, and pasting the pages was done by the women of the family. Gaudio shows how their work is informed by broader Caroline debates about church doctrine, word and image, the incarnation, and Mosaic law. Drawing on an impressive array of interdisciplinary scholarship and supported by beautifully reproduced plates, Gaudio 
makes a compelling case for the exegetical complexity and cultural richness of the Little Gidding concordances.

The first chapter considers the intersection between print culture and domestic handiwork. While the biblical texts used in the concordances were largely drawn from readily available editions of the Protestant Authorized Version, the religious images came from the Low Countries and were often Roman Catholic in doctrinal sympathy. Working with scissors and paste, the Little Gidding community deliberately created fragments of text and image in order to achieve a new, composite unity. For Gaudio, this is a means of negotiating the doctrinal differences between Protestantism and Roman Catholicism, as well as the fracture in the Caroline church between Arminianism and Calvinism. For some Puritans, Little Gidding was little more than an "Arminian Nunnery." Yet Gaudio's exploration of how public doctrinal dispute affects the pious work of domestic interiors moves beyond polemical labeling. He sensitively examines the broader significance of patchwork, embroidery, needlework, cutting, pasting, and seaming in the production of the concordances. This is high-quality scholarship that brings a number of disciplines into fruitful conversation with one another.

The second chapter expands on the claim that the concordances "are aids for the embodiment of scripture" (82). Gaudio traverses theological debates about the incarnation, the imagery of Christ's body on the cross, the discourse of experimentation, martyrdom, and the king's body, with great skill. The central question is whether the prints in the concordances offer the viewer a form of "virtual participation" based on a division between body and representation, or whether they are better understood as a kind of "incarnational experience" based on the inability of the image to "body forth real presence" (100). Gaudio argues that the concordances pose rather than answer this question: this is fair enough, but I would have enjoyed some further consideration of how this position is achieved rhetorically, and of the broader exegetical implications of the biblical verses that accompany the images.

The final chapter reads the concordances in relation to Caroline debates about Mosaic law. Do the New Testament Gospels render the Mosaic law largely obsolete, or does the law continue to resonate in the ceremonial practices of the church? William Laud, archbishop of Canterbury, favored the latter interpretation and his "beauty of holiness" agenda stressed that point even as it proved unpopular with many nonceremonialists and Puritans. Gaudio examines the Pentateuch harmony made for Laud and the discussion of Mosaic law and ecclesiology draws richly on the exegetical practice of typology, arguing that the printed image occupies the "questionable space between the law and the gospel" (161). This chapter would have benefited from some discussion of the rhetoric of moderation, which, as Peter Lake, Alexandra Walsham, and Ethan Shagan have shown, is central to debates around theology and ecclesiology alike. A couple of other quibbles might also be mentioned here. The claim that "few English Bibles contained illustrations" (19) is a dubious one. Important printings of the Great, Tyndale, Coverdale, Bishops', and Geneva Bibles contain religious illustrations, sometimes copiously so (see also the title page to 
the Old and New Testaments in the Authorized Version of 1613). And the idea that Charles I was a pacifist (168) glosses over the very martial first years of his reign as well as his battlefield activities during the Civil Wars. None of this detracts, however, from a fluent, original, and thought-provoking book that will be of interest to a wide range of early modern scholars.

Adrian Streete, University of Glasgow

Unconstrained Passions: The Architect's House as a Museum. Jaynie Anderson. Victoria: Lyon Housemuseum, 2016. viii + 96 pp. \$39.95.

In 1867 Jacob Burckhardt invited future historians to study the houses and collections of Renaissance architects. Though monographic studies have not been lacking, until now there has been nothing quite like this short, smart synthesis. Jaynie Anderson, an Australian specializing in Venetian painting, began thinking about the subject ever since her early work on Giorgione. This brought her to Asolo, where the pretentious (not necessarily in the bad sense) house of the architect Francesco Graziolo caught her attention. It is a rusticated fantasy of 1536 based on Serlio and Giulio Romano, who had just built a grand house for himself in Mantua. Being an avid student of historiography, especially in the Giorgione world, Anderson turned to the fascinating figure of Senator Giovanni Morelli, the pioneer of scientific connoisseurship, and to his circle in Milan. This got her to the house museum of Gian Giacomo Poldi Pezzoli, the pioneering collector of Tuscan and Venetian Renaissance art. In the age of Verdi's Nabucco the Poldi house museum offered defiance in the face of the occupying Austrians, who sent in troops to wreck the armor room. Poldi soon rebuilt, however, and turned the house into a public museum. His example was seminal for the great house museums of modern times, those of Isabella Stewart Gardner and Henry Clay Frick.

The catalyst for this study was an invitation to lecture at the Lyon Housemuseum, a combination residence, gallery, and art center near Melbourne built by the Australian architect, musician, and collector Corbett Lyon. Thus, half of this short book is devoted to Australian architecture and architect collectors from the 1950s to the present. It is the first half on the Renaissance that will be of interest to readers of this journal. Anderson traces the architect's house back to Alberti's redefinition of the status of the architect and to Filarete's proposal for an artist's house in his mythic city of Sforzinda. On a littleknown sheet in the Codex Ashburnham A, now in the Collège de France, Anderson finds Leonardo's proposal for a one-room dwelling plus studio where perspective devices can be set up and the daylight adjusted. It is tiny, and radically simple: "Small rooms or dwellings discipline the mind, large ones weaken it," said the artist (12). She surveys the more lavish houses of Raphael, good enough to be bought by a cardinal after his death, and of Antonio da Sangallo the Younger, later turned into Palazzo Sacchetti on Via Giu- 